\title{
A CLINOPYROXENE THERMOBAROMETRY TRAVERSE ACROSS COROMANDEL AREA, BRAZIL
}

\author{
Mdludlu $S^{(1)}$, Mabuza MB ${ }^{(1)}$, Tainton $K^{(2)}$, Sweeney $\mathbf{R J}^{(1)}$ and Skinner, $\mathbf{C}^{(3)}$ \\ ${ }^{I}$ De Beers GeoScience Centre, Johannesburg, South Africa ${ }^{2}$ De Beers Brasil, Brasilia, Brasil ${ }^{3}$ De Beers Exploration, \\ Johannesburg, South Africa
}

\section{INTRODUCTION}

De Beers Exploration has discovered a significant number of kimberlites in the Coromandel area, Brasil. The study area traverses approximately $440 \mathrm{~km}$ extending eastwards from the Proterozoic Brasilia belt onto the exposed Archaean basement of the São Francisco Craton (Fig 1). Clinopyroxene thermobarometry was combined with the garnet thermometry to establish a good estimation of sublithospheric P-T variations.

Clinopyroxene grains from a garnet lherzolite source (i.e. mantle-derived) were identified. In addition, the data were filtered to exclude potentially metasomatic grains, according to methods described in Nimis (1998) and Nimis and Taylor (2000). The thermometry results were compared with the Finnerty and Boyd (1984) calibration.

Thermometry data was also obtained from nickel analyses of garnet recovered from kimberlites in the region using the experimental calibration of Canil (1999).

\section{Results}

Nineteen kimberlite occurences were found to have sufficient (i.e. greater than 70) mantle-derived clinopyroxene grains for reliable interpretation. Maximum geotherms using $80 \%$ of the data (disregarding outliers) and profiled along a crosssection line $\mathrm{AB}$ (Fig 1). There are considerable geotherm variations in the extreme NW and SE of the section, and there is a suggestion that geotherms to the SE are comparatively elevated (Fig 2). It is of significance that the most profound disturbance of the geotherm (largest variations) occurs in the on-craton region to SE, using the cratonic boundary delineation of De Almeida (1978, Fig.1). The pipes containing the high temperature populations (labeled 'adiabatic' in Table 1) are also confined to the on-craton SE region. It is suggested that these heating events which disturbed the subcratonic mantle lithosphere in this region were ancient (Archaean) with lesser disturbances being prevalent in the later accreted lithosphere to the NW.

Some of the occurences show two distinct populations of grains in P-T space (e.g. Guara-01 and Dourados-06 in Fig 4). Further occurrences with such populations are indicated in Table 1. It is suggested from the orientation of the higher $\mathrm{T}$ population that these grains equilibrated along a mantle adiabat (Table 1, Fig 4). These populations indicate a mantle potential temperature in this region of between $1200^{\circ} \mathrm{C}$ and $1400^{\circ} \mathrm{C}$. Whether this influence was ancient or induced in the eruption process is undetermined.

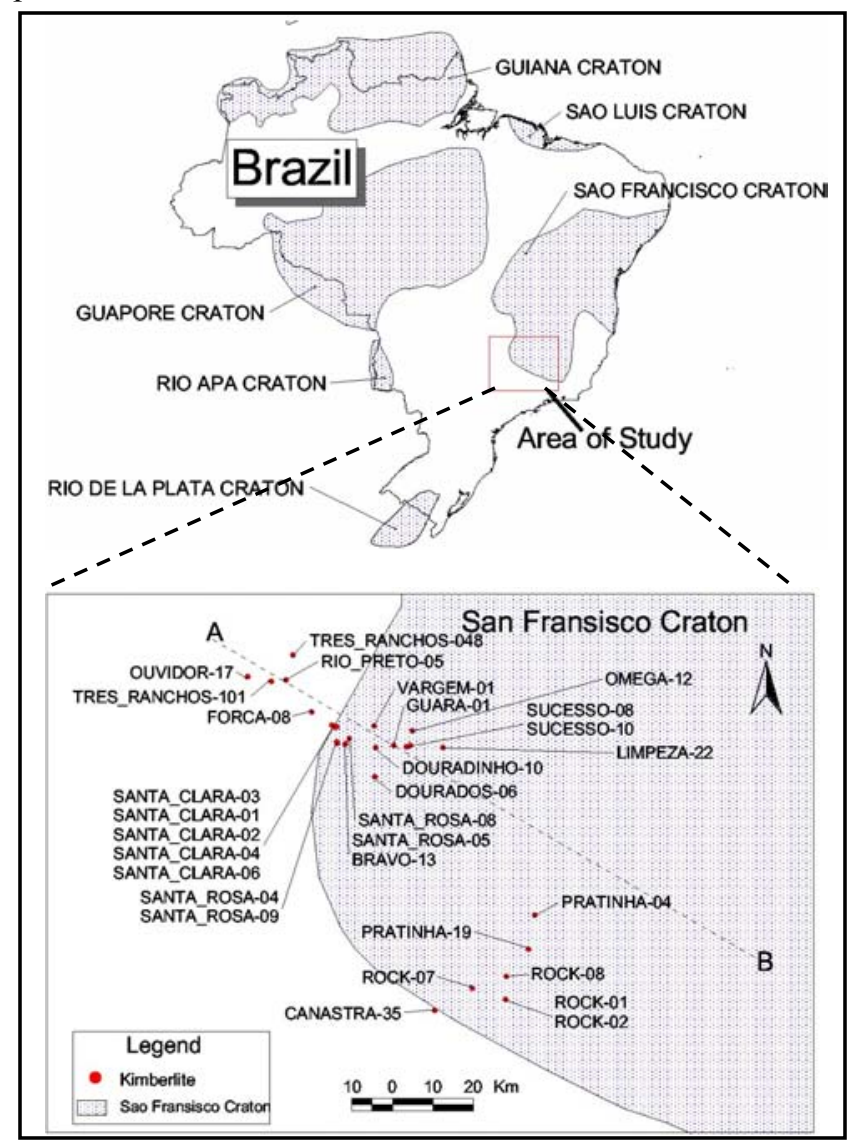

Figure 1: Locality map. 
In order to compare the clinopyroxene thermobarometry results, nickel thermometry data were calculated for occurrences with appreciable garnet grain analyses (>70) within the study area (Fig. 3). There are no observed consistencies between the clinopyroxene and garnet variations across the area of study.

Clinopyroxene thermo-barometry and garnet thermometry indicate complex P-T variations within the sub-lithospheric mantle of the Coromandel area. The extreme on-craton P-T variations are likely emulating the geological disturbances in the crust.

\section{REFERENCES}

Canil, D., 1999. The Ni-in-garnet geothermometer: calibration at natural abundances. Contr. Mineral. Petrol. 136, 240-246.

De Almeida F.F.M., 1978. The evolution of the Sao-Franciso and Amazon cratons compared with those of the northern hemisphere. Lib Dea Anais No XXX Cong Bras Geol. 6.

Finnerty, A.A., Boyd, F.R., 1984. Evaluation of thermobarometers for garnet peridotites. Geochim. Cosmochim. Acta. 48, 15-27.

Nimis, P., 1998. Evaluation potential from the compositions of peridotitic chromian diopside. European Journal of Mineralogy 10, 505-519.

Nimis, P., Taylor, W.R., 2000. Single clinopyroxene thermobarometry for garnet peridotites. Part 1. Calibration and testing of a $\mathrm{Cr}$-in $\mathrm{Cpx}$ barometer and an enstatite-in-Cpx thermometer. Contr. Mineral. Petrol. 139, 541-554.

Contact: S Mdludlu, Geoscience Centre, PO Box 82232

Southdale, South Africa, 2135, E-mail:

saseka.mdludlu@debeersgroup.com

Table 1: Geotherm data of the occurences with sufficient clinopyroxene grains (geotherm data was defined using P-T plots as shown in figure 4).

\begin{tabular}{|c|c|c|c|c|c|c|c|c|}
\hline \multirow[b]{2}{*}{ Occ Name } & \multirow[b]{2}{*}{ Population } & \multirow{2}{*}{$\begin{array}{l}\text { Population } \\
\text { size }(n)\end{array}$} & \multicolumn{3}{|c|}{ Geotherms $\mathrm{mW} / \mathrm{m}^{2}$} & \multirow{2}{*}{$\begin{array}{l}\% \mathrm{D} / \mathrm{G} \\
\text { grains }\end{array}$} & \multirow{2}{*}{$\begin{array}{c}\text { Distance from the cross } \\
\text { section line }(\mathrm{d}, \mathrm{Km})\end{array}$} & \multirow[b]{2}{*}{$\mathrm{T}_{\max }\left({ }^{0} \mathrm{C}\right)$} \\
\hline & & & Max & $\begin{array}{l}\text { Mean }(\sim 80 \% \text { of } \\
\text { dataset) }\end{array}$ & \begin{tabular}{|l} 
Error \\
$(+/-)$
\end{tabular} & & & \\
\hline Tres Ranchos-48 & 1 & 114 & 43 & 37 & 1 & 9 & 15 & 1380 \\
\hline Tres Ranchos-101 & 1 & 76 & 40 & 36 & 1 & 70 & 8 & 1070 \\
\hline Forca-08 & 1 & 159 & 48 & 39 & 1 & 8 & 6 & 1090 \\
\hline Santa Clara-01 & 1 & 289 & 46 & 44 & 1 & 51 & 4 & 1250 \\
\hline Santa Clara-04 & 1 & 105 & 39 & 36 & 1 & 84 & 4 & 1120 \\
\hline Santa Clara-06 & 1 & 226 & 49 & 37 & 1 & 71 & 4 & 1260 \\
\hline Santa Clara-02 & 1 & 85 & 45 & 38 & 1 & 53 & 3 & 1100 \\
\hline Santa Rosa-09 & 1 & 229 & 45 & 37 & 1 & 69 & 11 & 1090 \\
\hline Santa Rosa-04 & 1 & 82 & 43 & 37 & 1 & 68 & 11 & 1230 \\
\hline Santa Rosa-08 & 1 & 115 & 45 & 38 & 1 & 29 & 4 & 1130 \\
\hline Bravo-13 & 1 & 141 & \multicolumn{3}{|c|}{ Adiabatic } & 50 & 8 & 1190 \\
\hline Santa Rosa-05 & 1 & 74 & \multicolumn{3}{|c|}{ Adiabatic } & 53 & 8 & 1190 \\
\hline Vargem-01 & 1 & 159 & 46 & 37 & 2 & 79 & 14 & 1200 \\
\hline Douradinho-10 & 1 & 86 & 41 & 36 & 1 & 43 & 3 & 1040 \\
\hline \multirow{2}{*}{ Guara-01 } & 1 & 201 & 50 & 44 & 1 & 28 & 13 & 1300 \\
\hline & 2 & 175 & \multicolumn{3}{|c|}{ Adiabatic } & 21 & 13 & 1440 \\
\hline Omega-12 & 1 & 74 & 40 & 36 & 1 & 26 & 28 & 960 \\
\hline \multirow{2}{*}{ Dourados-06 } & 1 & 128 & 48 & 45 & 2 & 23 & 12 & 1030 \\
\hline & 2 & 86 & \multicolumn{3}{|c|}{ Adiabatic } & 73 & 12 & 1300 \\
\hline \multirow{2}{*}{ Sucesso-10 } & 1 & 37 & 54 & 53 & 1 & 2 & 17 & 1000 \\
\hline & 2 & 34 & 39 & 38 & 1 & 8 & 17 & 1485 \\
\hline Limpenza-22 & 1 & 126 & 49 & 45 & 1 & 21 & 33 & 1230 \\
\hline
\end{tabular}




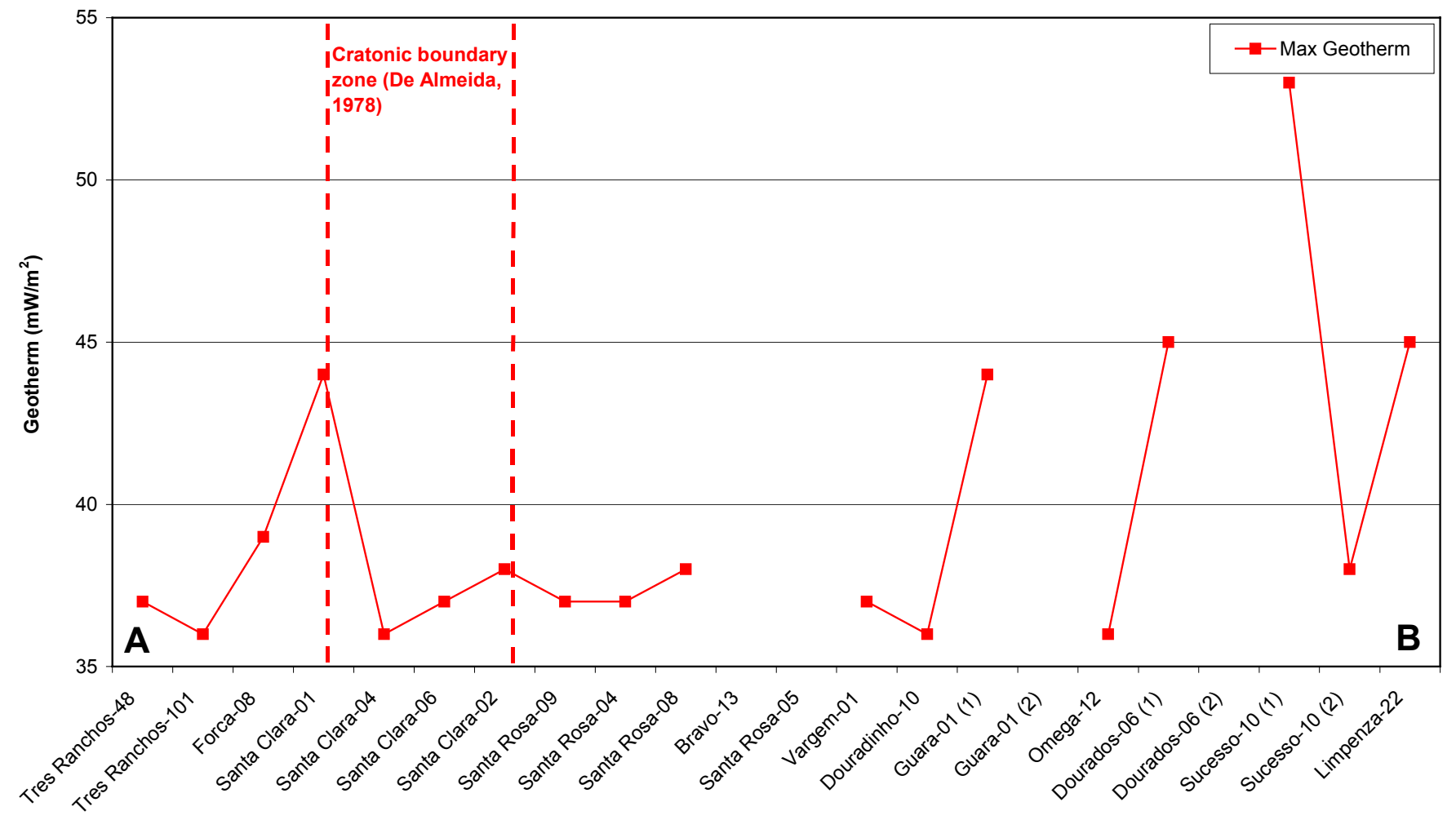

Figure 2: Clinopyroxene thermo-barometry profiles across section AB in figure 1 (occurences that follow an adiabat are indicated by gaps).

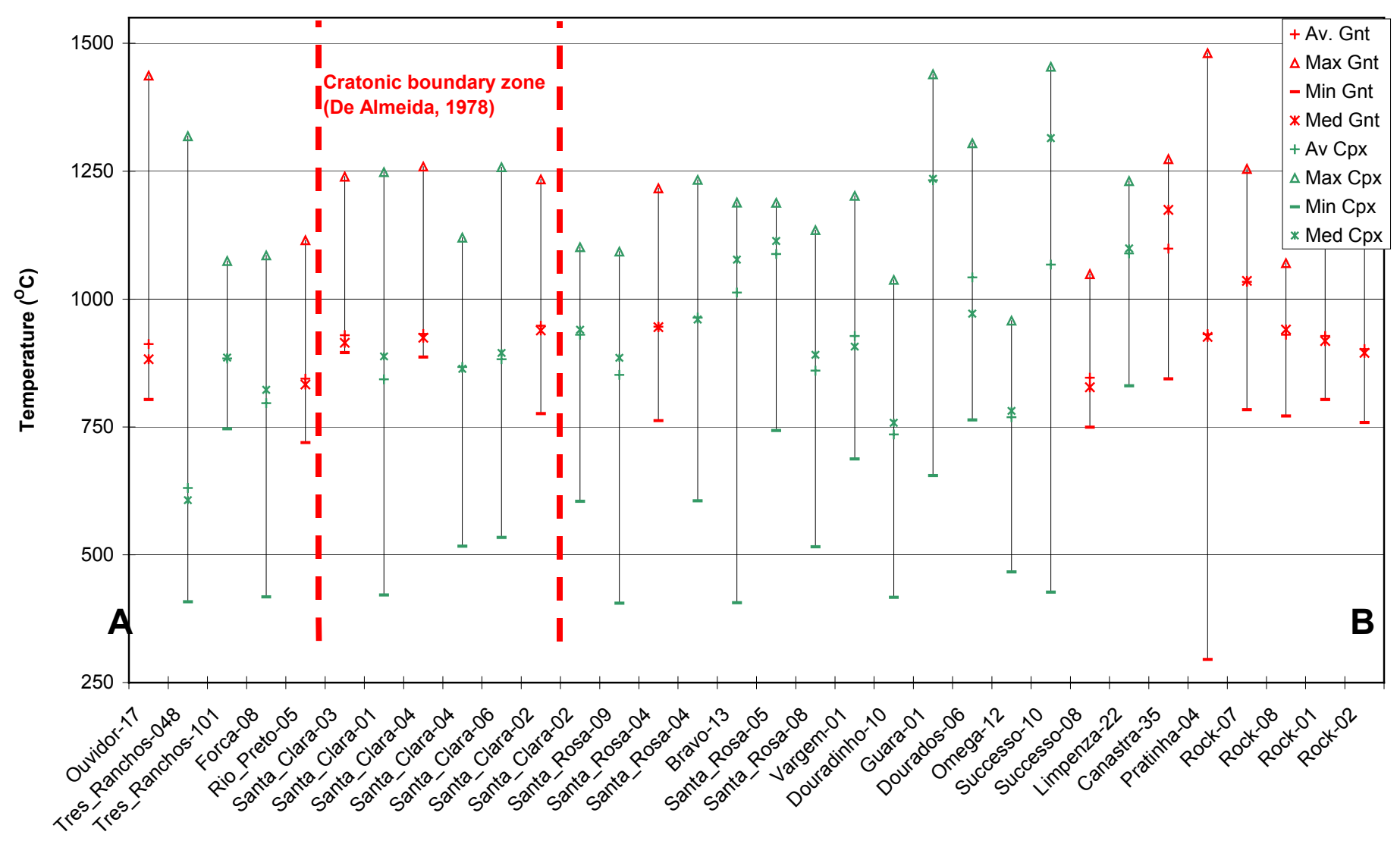

Figure 3: Clinopyroxene and garnet thermometry profiles across section AB (range, average and median). 


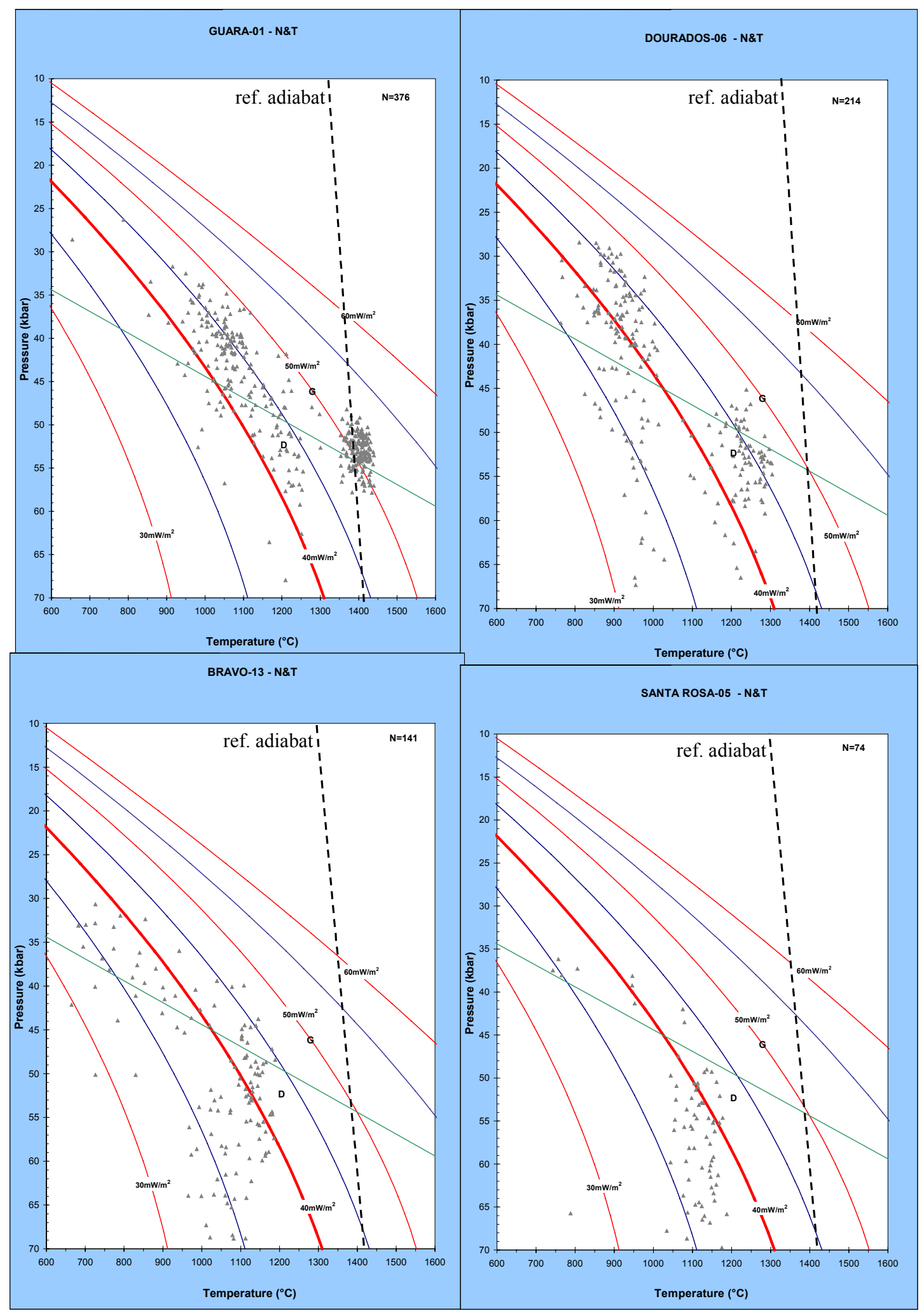

Figure 4: Examples of thermo-barometry plots of several occurrences in the area of study from which geotherms have been calculated and listed in Table 1. 